\title{
Könyvszemle
}

SIPOS JÚLIA GONDOZÁSÁBAN

\section{A DIGITÁLIS PEDAGÓGIA SIKERÉNEK ZÁLOGA A TECHNOLÓGIATUDATOS TANÁR}

Ahhoz, hogy a pedagógusok kellő kompetenciára és tudatosságra tegyenek szert az online oktatásban, kitünő segítséget nyújt Szüts Zoltán A digitális pedagógia elmélete címen megjelent új könyve.

A jól ismert médiakutató kötetének különös és egyáltalán nem örömteli aktualitást adott a koronavírus-járvány, amelynek egyik következményeként az iskolai oktatást hirtelen át kellett állítani a jelenlétiről az online tanításra. Az interneten keresztül zajló órák megtartása a pedagógusok számára hatalmas kihívást jelent emberileg és szakmailag egyaránt. Ennek egyik oka arra vezethető vissza, hogy a legtöbb tanárnak a korábbi stúdiumaiban nem kapott - régebben nem is kaphatott - helyet az online kommunikáció- és médiaismeret, így sok tanár tudástárából hiányoznak a digitális pedagógia biztos elméleti alapjai.

Szüts határozott álláspontja szerint a tanítás és a tanulás egyaránt az információ megosztásának, befogadásának, feldolgozásának folyamataként definiálható, ezért a digitális pedagógia kérdéskörét deklaráltan a kommunikáció- és médiatudományi kontextusba helyezve tárgyalja, és erőteljesen érvel amellett, hogy a világhálón keresztül zajló iskolai oktatás alapjaiban változtatta meg az oktatás fél évezredes rendszerét. A 26. oldalon például így ír erről: a könyvnyomtatás feltalálása óta ,egyetlen kommunikációs forma vagy médium sem épült be ilyen erősen a kultúra és a társadalom, a munkavégzés és az irányítás, ezzel pedig az információszerzés és tanulás alrendszereibe, mint az internet [...]. A digitális eszközökkel támogatott [...] online ökoszisztéma paradigmaváltást hozott a tanítás és tanulás evolúciójában."

Mint oly sok más szakterület, a didaktika világa is komplex, egységes univerzumot alkot az online kommunikáció és média elméletével és jelenségeivel, ezért a digitális pedagógia elméleti keretei kidolgozásának előfeltétele az online világ rendszerének, fejlődésének és dinamikájának feltérképezése, megismerése. A kötet témájához illően Szüts a virtuális közegbe transzformálja a klasszikus osztályterem és tanítás fogalmát, és hangsúlyozza, hogy az információs társadalomban a tanulókat a kiterjesztett osztályteremben ,kiterjesztett funkciókkal bíró tanár" tanítja. 
Szüts Zoltán eddigi munkássága arról tanúskodik, hogy öszintén hisz az online kommunikáció pozitív társadalmi hatásában, illetve a digitális pedagógia paradigmatikus váltást jelentő térnyerésének kedvező voltában. A teljes kép érdekében azonban felsorakoztat ún. technopesszimista véleményeket is, például David Lewin és David Lundie 2016-ban írt tanulmányából: ,a digitális pedagógia rövid távon [...] nem lesz képes forradalmasítani a tanítás és tanulás folyamatát a digitális tananyagok és az intuitív elektronikus tanulási környezetek széles körü elterjedése ellenére. A változások elörejelzésénél [...] figyelembe kell venni a társadalmi, etikai és episztemológiai tényezőket, amelyek a transzformációt nehezítik. Amíg ugyanis a digitális eszközök használata már hosszú ideje a mindennapi élet részévé vált, a kulturális, és különösen az oktatási intézmények még nehezen birkóznak meg az új jelenségek és fejlesztések implementálásával." (60.)

A kétkedők vélekedése dacára Szüts azonban továbbra is úgy véli, a technológia tudatos használata korábban nem látott előnyökkel járhat. És, hogy az előnyök csak feltételes módban értendők, arra a szerző is kitér a 6. fejezetben. „A digitális szakadék, ha nem is óriási, de még mindig létezik. Nem feledkezhetünk meg tehát azokról sem, akik »eszköztelenek«.” Az alacsony jövedelem miatt sok családnak „kihívást jelent az eszközök beszerzése”, emellett erősen kérdéses, hogy az érintett szülő „,mennyire uralja és birtokolja a szükséges tudást”, és további gondot okoz, hogy a szabad hozzáférés helyett egyre több az előfizetés ellenében elérhető tartalom (260.).

Talán az olvasót is meglepi, hogy a Pedagógiai diskurzusok az információs társadalomban címü rész első fejezete $A$ digitális technológia diszruptív jellege címet viseli, és e felütés révén a téma meglehetősen nagy hangsúlyt kap. A „könyvnyomtatás óta nem volt rá példa, hogy egy technológia - lásd telefon, rádió, a film vagy a televíziózás - ilyen szélsőséges, diszruptív hatással legyen az oktatásra" - írja a szerző (49.). A diszruptív jelzőt a kreatív szétbomlasztásnak felelteti meg, de ismeretes, hogy a diszruptív innováció kifejezést ennél keményebb szavakkal, romboló, zavaró innovációként ültetik át magyarra - ugyanis az ide sorolható innovációk alapjaiban kérdőjelezik meg a fennálló rendszereket, az elterjedt gyakorlatot, az üzleti modelleket. Szüts azt a folyamatot nevezi diszruptívnak, melynek révén a korábbi hagyományokat átértelmező módszerek, megoldások és gyakorlatok jelennek meg az oktatásban.

Hosszasan lehetne kivonatolni a gazdag mondanivalójú fö fejezeteket, erre azonban a recenzió szükre szabott terjedelme nem ad lehetőséget. A téma megismerését jól szolgálja az a rész, amelyben a szerző az információs társadalomnak, a technológia által támogatott kommunikációs folyamatoknak, valamint a médiaplatformoknak a neveléstudományra gyakorolt hatását vizsgálja. Érdekes csoportokat alkotnak a különböző megközelítésmódok: az eszközcentrikus, a történeti, az elméleti és jelenségközpontú, valamint a technooptimista, biológiai optimista és technopesszimista szemléletmód. Ehhez a részhez szervesen illeszkedik $A$ jövö 
digitális. Az információs társadalom és a digitális kultúra címü fejezet, amelyben az olvasó számottevő ismeretekre tehet szert az információs társadalomról, a digitális kultúráról, az online nyilvánosságról, a negyedik ipari forradalomról.

Szerzőnk a neveléstudomány hagyományos didaktikai háromszögéből csak az egyik alkotóelemre, a tanári személyiségre koncentrál, őt állítja a vizsgálódás fókuszába, hiszen az online térben zajló tanítás hatékonysága a pedagógus digitális kompetenciáján múlik.

Szűts elsődleges célja a digitális pedagógia elméleti keretének megalkotása volt, emellett azonban kidolgozta a magyar valóságra reflektáló távoktatási modellt, amelynek tanulmányozása a gyakorló pedagógusok számára kiemelten fontos. A szerző ebben a részben összegzi a tanulói jelenségeket, megnevezi a digitális pedagógia kihívásait, meghatározza, hogyan érvényesülhetnek az osztályterem kiterjesztésére vonatkozó módszertani ismeretek a jelenléti oktatás környezetében, megfogalmazza a távoktatás gyakorlatára vonatkozó, specifikus módszertant, majd végül felvázolja az oktatás (egyik) lehetséges jövőképét, melynek fontos eleme lesz a Big Data és a mesterséges intelligencia használata.

A téma a Covid-világjárvány idején jelentősen felértékelődött, de Szüts Zoltán könyve korántsem a tantermen kívül elrendelt digitális oktatási munkarendben jelent kitűnően használható segítséget a pedagógusok számára, hiszen alig van olyan iskola és olyan tantárgy, amelyhez a világhálót ne vennék igénybe a jelenléti oktatás során is. A témában való elmélyülést a kötet végén található közel 500 tételes bibliográfia segíti. A rendkívül hasznos, gördülékeny stílusban megírt, érdekfeszítő könyv nyomtatott és digitális kiadása egyszerre látott napvilágot.

(Szüts Zoltán: A digitális pedagógia elmélete. Budapest: Akadémiai Kiadó, 2020. 296 o. A digitális kiadás az Akadémiai Kiadó MeRSZ-adatbázisában érhetö el: DOI: $10.1556 / 9789634545859)$

Tószegi Zsuzsanna

c. egyetemi docens Eötvös Loránd Tudományegyetem Bölcsészettudományi Kar Könyvtár- és Információtudományi Intézet 